\title{
ポリイミド容量型湿度センサの信頼性の向上
}

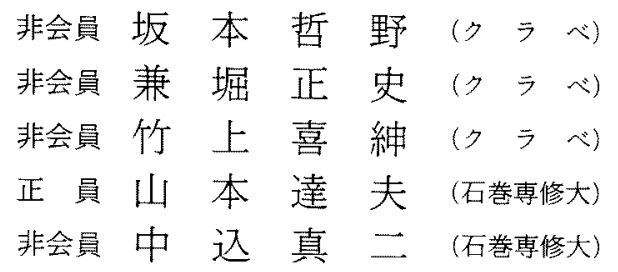

\section{Improvement in Reliability of a Polyimide Capacitive Humidity Sensor}

Tetsuya Sakamoto, Non-member, Masasi Kanehori, Non-member, Yoshinobu Takegami, Non-member, (Kurabe Industrial Co., Ltd.) Tatsuo Yamamoto, Member, Shinji Nakagomi, Non-member (Ishinomaki Senshu University)

This paper describes reliability of a capacitive humidity sensor based on the moisture sensitivity of polyimide. The sensor consists of a simple polyimide capacitor structure fabricated directly on $\mathrm{Si}$ substrate which is used as a lower electrode. Polyimide layer was coated with spinner by the thickness of about $1.2 \mu \mathrm{m}$, and then a comb-shaped upper Au electrode was attached on it, which was about $10 \mathrm{~nm}$ in thickness. Moreover, another type of polyimide layer was formed on the top surface as a protective one.

In order to improve the sensitivity and stability characteristics, the mixing of two different kinds of polyimide resin was considered. As a function of the polyimide mixing ratio, the sensitivity for humidity variation and the durability for high temperature and high humidity conditions were studied.

Characteristics of the sensor such as sensitivity, linearity, hysteresis, response time and durability were evaluated. The durability has been examined in various extreme environment such as high temperature, high humidity, temperature cycles and wetting cycles with dew. Long-term stability was typically less than $5 \% \mathrm{RH}$.

キーワード：ポリイミド，湿度，センサ，容量，信頼性

\section{1.まえがき}

物や素材に対して最適な湿度環境を維持すること は, 半導体や新素材産業だけてなく, 食品, 瀻維, 機 械などの分野に扔いて品質管理上重要な要素となって いる。更に人間に対する快適性も求めら机，ビルの空 調加ら家庭用エアコンにも湿度を計測し制御すること が必要となってきた。このような用途拡大に伴って検 出条件や検出湿度範囲も多岥にわたることとなり，低 湿度加ら高湿度までの広い湿度領域において高精度な 湿度計測が可能で，かつ信頼性の高いセンサが求めら
れている。

高分子材料を感湿材としたセンサは, 温度依存性や ヒステリシスが小さく，常温付近で高い信頼性を有し ている(1)。高分子膜を用いた湿度セン゙サは，湿度変化 に対応した交流抵抗の変化を検出する抵抗型(2) 電容量の変化を検出する容量型(3) とがある。抵抗型は 比較的安価であるものの, 抵抗值が指数関数的に变化 するため, 相対湿度 $30 \%$ 以下で感度, 精度が低下し， 検出できなくなるという尔点をもっている(む)

一方, 容量型は相対湿度に対して直線的に容量值が 变化するので，10〜30\%の低湿度領域においても精度 
良く測定ができ，しかも約 10 秒の応答速度である。 しかし比較的高価であったため, 湿度計測器のなかで センサとして使用される程度の狭い利用範囲にとどま っていた。

高分子膜を用いた容量型湿度センサのうち Si 基板 を用いたものには二種類ある。一つは，Si 基板を単 に支持基板としてのみ使っているもの(5)(6)であり，Si 基板上に絶縁譄 $\left(\mathrm{SiO}_{2}\right)$ を形成し，その上に金属電極/ 高分子膜/金属電極からなるコンデンサ領域を形成し ている。他方は, 著者らが行った $\mathrm{Si}$ 基板を片側の電 極とする夕イプ(7)(8)であり，Si 基板に直接高分子膜を 形成し，Si 基板と金属電極とで高分子膜を挟んだ構 造である。Si 基板に直接高分子膜を形成すると製作 工程が籍略化でき，低価格，量産化の利点がある。本 研究は後者のタイプのセンサの, 特に信頼性の向上に 関するものである。

感湿膜として用いたポリイミド樹脂は高酎熱，高絶 縁性，酎溶剂制にも優れた樹脂である。また，湿度変 化により吸着水分量が変わることで実効誘電率が変化 し，静電容量の変化として湿度を検知することができ る。従って，ポりイミド磻の特性がセンサとしての特 性に大きく影響する。そこで著者らは，性質の異なる ポりイミド樹脂を配合して用いることにより，互いの 性質を合わせもったセンサを制作できることを見いだ し，この技術を用いて感湿特性抢よび経時特性ともに 優れた湿度センサを実現したので報告する。

\section{2. 湿度センサの構造}

図1に感湿菜子チップの構造を示す。低抵抗（例え ば $0.015 \Omega \cdot \mathrm{cm})$ ○形 $\mathrm{Si}(100)$ 基板の零面にオーミ ック電極作成後, 表面側に樹脂のスピンコーティング

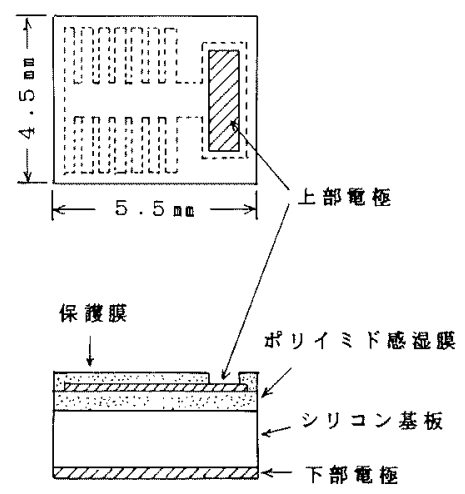

図 1 感湿菜子の構造

Fig. 1. Structure of the humidity sensor.

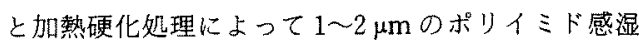
膜を形成する。その上に図のような概型上部電極とし て Au 約 $10 \mathrm{~nm}$ 蒸着し, 更に電極保護のためポリ イミド膜約 $500 \mathrm{~nm}$ を形成する。チップサイズは $4.5 \times 5.5 \mathrm{~mm}$ である。

\section{3. 感湿膜の評価}

著者らは $\mathrm{Si}$ 基板に直接ポリイミド樹脂の層を形成 した構造をっつ容量型湿度センサの開発過程におい て, ポリイミド層の形成ではポリアミック酸タイプの ピロメリット酸型扔よびビフェニル型の単一のポリマ を用いてきた。しかし，ピロメリット酸型では湿度に 対する容量値の変化量は大きいが, 高温高湿に拈ける 信頼性に乏しく，ビフェニル型では高温高湿に沾ける 信頼性は比較的あるものの，湿度に対する容量変化量 が小さいという傾向があった。

このような問題を解決するため，特性の異なる二種 類のポりイミド樹脂を適切な割合で配合したものを感 湿材として用いると，互いの欠点を補うことができる ことが判明した。

実験には， $25^{\circ} \mathrm{C} ・ 20 \% \mathrm{RH}$ におる容量（例えば，

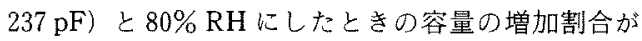
1.171 倍であるポリイミド樹脂 $A$ と, 容量の増加割 合 1.097 倍のポりイミド樹脂 $B$ 二種類のポりマを 混合して用いた。雨者は所定の比率となるように科 鴜し, 十分汃くはん混合した後，必要に応じ粘度調整 のため溶剤を加えてスピンコーティングにより塗布し た。図 2 に二つのポリイミド樹脂の配合率と湿度変化 に対する静電容量の変化率の関係を示す。配合率（固

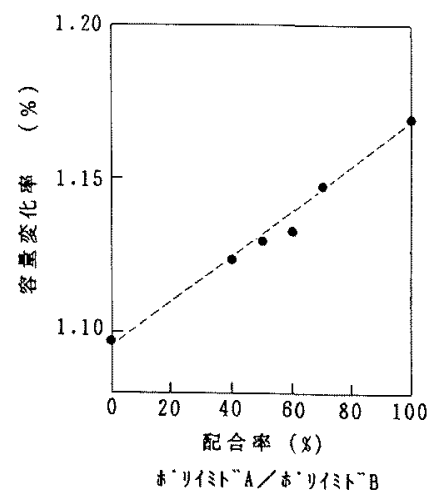

図 2 湿度変化に対する容量変化率の ポりイミド配合率依存性

Fig. 2. Capacitance change with humidity as a function of the polyimide mixing ratio. 


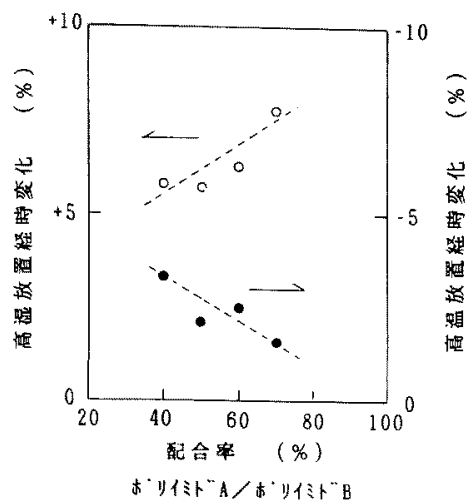

図 3 経時特性のポリイミド配合率依存性 Fig. 3. Stability characteristics as a function of the polyimide mixing ratio.

形分濃度比）に応じて湿度に対する容量变化率は直線 的に変化する。従って，配合割合を調節することによ り湿度に対する容量の変化率を自由に設定できる。 製作した湿度センサは，信頼性試験の一つとして， 高湿放置では $40^{\circ} \mathrm{C} \cdot 90 \% \mathrm{RH}$ 雾囲気・ 200 時間, 高温 放置では乾燥雲囲気・ $60^{\circ} \mathrm{C} \cdot 200$ 時間の経時試験を行っ た。この高湿放直時における経時変化の割合 $(0)$ ，お よび高温放置時における経時変化の割合 (・)を, 二種 類のポりマの配合率(ポりイミド $A$ /ポりイミド $B$ )に 詨してプロットした結果を図 3 に示す。ポリイミド $B$ は高湿経時特性がポりイミド $A$ に比べて良いの での印で示されるように $B$ の割合増加に伴って高 湿経時特性が良くなる。逆にポりイミド $A$ は高温経 時特性が良いので，・印で示されるようにAの割合 を增やすと高温経時特性が改善される。このことか ら，性䐝の䔬なるポリマを組合せることにより，単一 のポりマがもつ点補いながら使用環境の特異性に 合わせて, 経時特性の異なるセンサを作成可能とな る。本研究では, 高湿経時特性と高温経時特性の両方 を満足するように，以下に示寸素子のポりイミド配合 割合は $50 \%$ とした感湿膜で実験を行った。

\section{4. 製作プロセスの最適化}

感湿膜の厚さが薄いほど静電容量値が大きくなり， 同時に湿度変化に対する容量変化率が增加する傾向に あるが，耐圧低下を生じたり，リーク電流が発生する 原因となりやすい。ここでは感湿膜厚を約 $1.2 \mu \mathrm{m} て ゙$ 一定として素子を作成した。

櫛形の上部 $\mathrm{Au}$ 電極は水分の通り道にもなるので, その厚さがセンサの応答速度に大きく影響を与えると

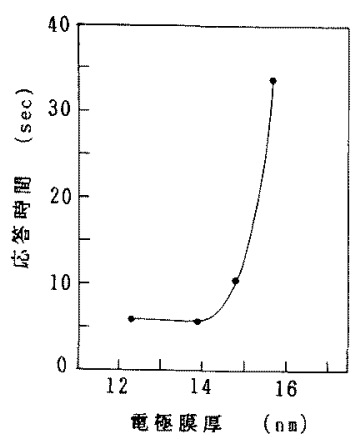

図 4 応管時間の上部 $\mathrm{Au}$ 電極膜厚依存性 Fig. 4. Response time as a function of the thickness of upper Au electrode.

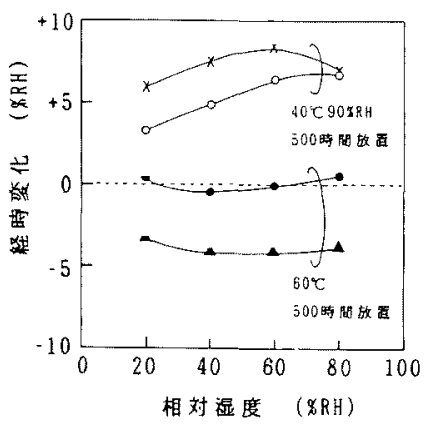

○：保護用ポリイミト膜 $(400 \mathrm{~nm})$ 付き メ、：保護用レジスト膜 $(180 \mathrm{~nm})$ 付さ

図 5 保護膜に上る耐久性の向上 Fig. 5. Improvement in durability by polyimide protective layer.

考えられる。Au電極膜厚を変えて製作した湿度セン サの応答時間を図 4 に示す。Auの蒸着膜厚が約 15 $\mathrm{nm}$ 以上になると急激に応答速度が遅くなっている。 このことから, Au膜原が約 $15 \mathrm{~nm}$ 以上の領域では, 電極が水分の透過を妨げて抢り，乙れ以下の場合には ポリイミド上でAuが島状となって水分の透過性が保 た机ていると考えられる。立た $\mathrm{Au}$ 電極の $\mathrm{Si}$ 基板に 対する面積者 $42 \sim 58 \%$ で变化させたが，応答時間は 4.3〜6.5 秒の範囲でばらついており，この範囲での 面積変化に対する応答速度の依存性は見られていな い。このことからもAu電極の水分透過性が裹付汀ら れる。

$\mathrm{Au}$ 電極は約 $10 \mathrm{~nm}$ と薄いことも南り，機械的な保 護と有害がスなどの接触を避ける必要がある。そこで 電極保護のために感光性ポリイミドを用いて $500 \mathrm{~nm}$ の保護膜をつけている。図 5 は保護膜を形成したこと

電学論 C, 113 巻 5 号, 平成 5 年 


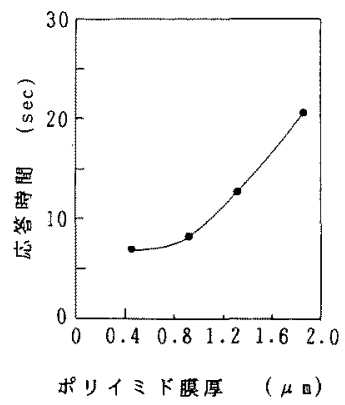

図 6 応答時間のポリイミド保護膜厚依存性

Fig. 6. Response time as a function of the thickness of polyimide protective layer.

による酎久性の改善を示す図である。 $400 \mathrm{~nm}$ 厚のポ リイミド層を保護膜としてつけたセンサと, $180 \mathrm{~nm}$ 厚のレジストをつけたセンサについて, $40^{\circ} \mathrm{C} \cdot 90$ $\% \mathrm{RH} \cdot 500$ 時間放置後および $60^{\circ} \mathrm{C} \cdot 500$ 時間放置後の 処理前との変化分 $(\% \mathrm{RH})$ を各相対湿度について示 してある。いずれの酎久試験においても，400 nm 厚 のポリイミド保護膜を有するセンサは経時変化が小さ くなり耐久性が向上している。

一方，図6に示すように保護膜の厚さを変えて応答 時間を測定すると，約 $850 \mathrm{~nm}$ 以下では保護膜を付け たことによる芯答速度の低下はほとんどないので，こ の領域では保護膜が多孔質のように水分を透過し，応 答性の鈍化なしに耐久性の改善が可能となる。

\section{5. 湿度センサの特性}

〈5・1〉感湿特性 素子の霜囲気の温度を一定に したまま，相対湿度を10 90\% RHの範囲で増加ま たは減少させたときの静電容量の変化を図7に示す。 湿度の発生には，所定の温度で飽和水蒸気圧に保った 相対湿度 $100 \%$ 架気と乾燥空気とを適当な割合で混 合し，所望の相対湿度雾用気を得る分流式湿度発生装 置を用いた。容量の測定はLCRメータを用い, peak-to-peak $1 \mathrm{~V}$, 周波数 $1 \mathrm{kHz}$ で行い, 各湿度で の保持時間は10分間とした。容量值は相対湿度に対 してほぼ直線的に約 $0.7 \mathrm{pF} / \% \mathrm{RH} て ゙$ 変化し，10〜90 \% RH の広い湿度領域でほとんど補正が不要で, ま たヒステリシスも $2 \% \mathrm{RH}$ 以下である。

〈5・2〉温度特性図 8 に $10 \sim 60^{\circ} \mathrm{CO}$ 範囲で娜定 した感湿特性をす。温度上昇に伴って静電容量值は 隇少する方向に移動するが, 特性の直線性とその公配 は変わらない。この㵊度領域において湿度の変化は

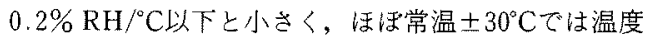

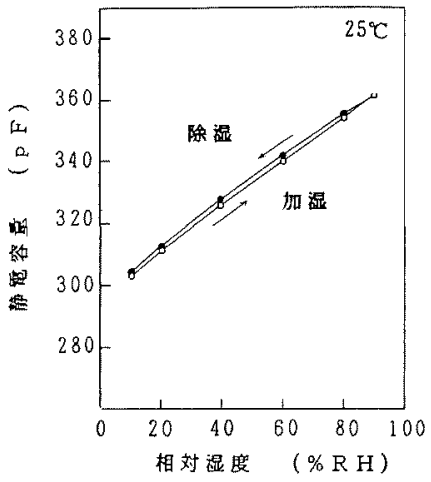

図 7 感湿特性のヒステリシス

Fig. 7. Typical graph of capacitance as a function of relative humidity cycle.

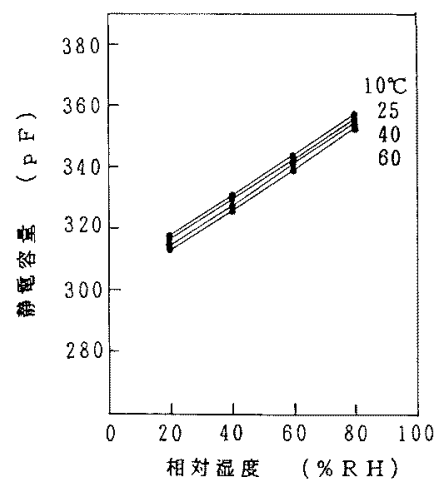

図 8 温度依存性

Fig. 8. Typical graph of capacitance as a function of relative humidity for several values of temperature.

補償なしに高精度の測定に利用できる。

〈5・3〉応答特性 図 9 に相対湿度を $30 \% \mathrm{RH}$ 加ら $90 \% \mathrm{RH}$ に增加もしくは $90 \% \mathrm{RH}$ から $30 \% \mathrm{RH}$ に減少させたときの容量変化を相対湿度に換算して応 答特性として示す。加湿, 除湿ともほほ10秒以下て 応答して扔り，十分な応答速度を有している。

〈5・4〉信頼性図 10 に $40^{\circ} \mathrm{C} \cdot 90 \% \mathrm{RH}$ に放置 したときの経時特性を示す。信頼性試験では実験に先

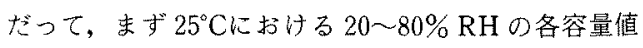
を測定する。続いて $40^{\circ} \mathrm{C} \cdot 90 \% \mathrm{RH}$ の第用気に所定時 間放置し, 室内に取出して 1 時間後, 各相対湿度で容 量値を再び測定する。最初に測っておいた容量と湿度 の関係を使って, 测定された容量值がどれくらいの相 対湿度を示すことに相当するかを求め，放置時間に対 


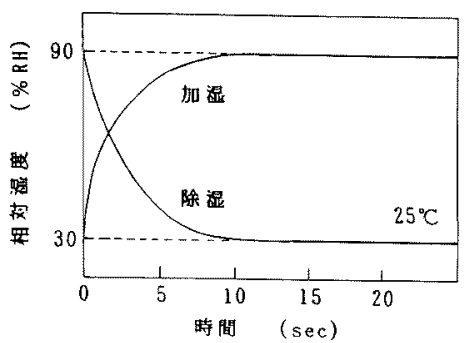

图 9 応答特性

Fig. 9. Time response curves of the sensor.

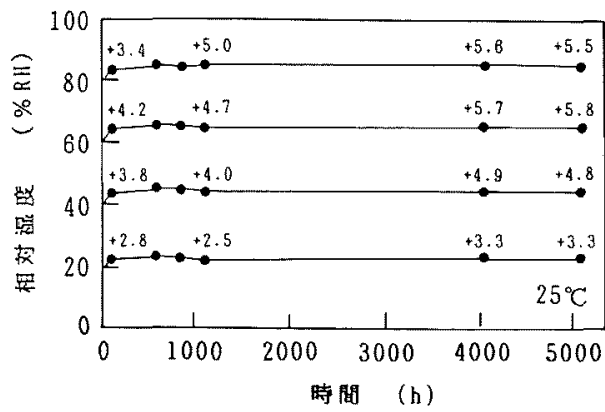

圀 10 高温高湿放置経時特性

Fig. 10. Long term durability of the sensor in a high temperature and high humidity atmosphere.

する湿度変化として示している。図中の数子は初期值 加の変化分（\%RH） 表している。図から明らか なように，初期において，どの湿度に扔いても3〜4 $\%$ RH 程度の容量增加を起こすが，その後約 500 時間 まではゆっくりした増加で，その以降は 5,000 時間を 経過してもほとんど変化がなく，5\% RH以内の経時 変化にとどまって安定している。

図 $11 に 60^{\circ} \mathrm{C}$ 乾燥霖囲気中に放䈯したときの経時特 性を示す。測定法およびグラフの表示法は図 10 と同 様である。初期に拈いて，図 10 の場合とは逆に2 3 $\% \mathrm{RH}$ 程度の容量值の減少を示すが, その後, 初期 値から 3 4\% RH の経時変化のまま安定している。

図 12 に熱衝撃に対する経時特性を示す。 $25^{\circ} \mathrm{C} \cdot 60$ $\% \mathrm{RH} て ゙ の$ 容量值を測定後, $10^{\circ} \mathrm{C} \cdot 30$ 分間と $60^{\circ} \mathrm{C} \cdot 30$ 分間とを 1 サイクルとして所定のサイクル後に再び測 定した容量值を湿度に換算して示してある。この範囲 の熱衝撃に対してはほとんど影響されずに約1\% RH 以内の変動で安定に動作している。從って, 通常の室 内で経験する温度㧍よび湿度の範囲内では, 容量値が 初期の值から大きく変化してしまうといった特性劣化

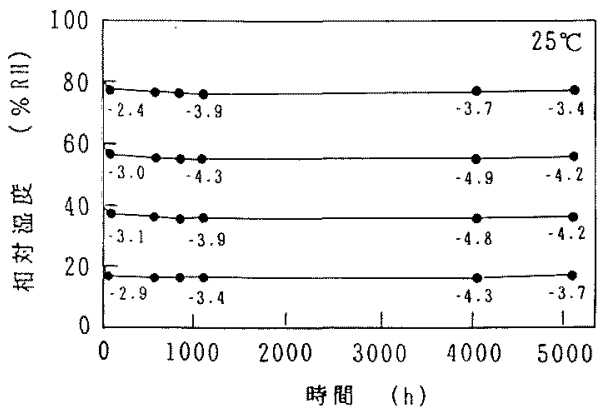

図 11 高温放置経時特性

Fig. 11. Long term durability of the sensor in a high temperature and dry atmosphere.

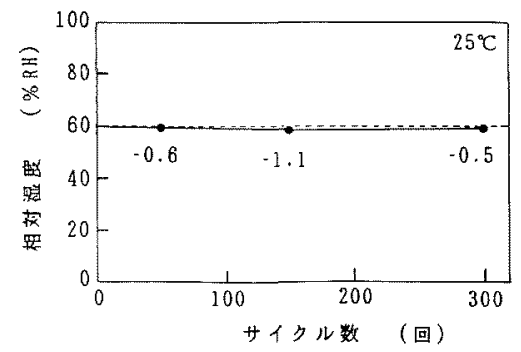

図 12 温度サイクル試験

Fig. 12. Effects of the temperature cycles.

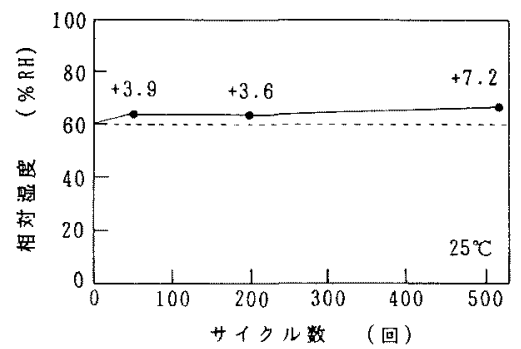

図 13 結露サイクル試験

Fig. 13. Effects of the wetting cycles with dew.

を生じないといえる。

次に，素子に結簬を発生させたときの耐久性につい て図 13 に示す。超音波加湿器を用いて15秒間センサ に噴霧結露後，30 分間自然乾㰒するのを 1 サイクル とし, 静電容量測定は 24 時間の自然乾燥後に行った。 容量の增加による相対湿度の変化割合は，図 10〜図 12 に示した信頼性試験の場合に比べわずかに増加し ているが, 結露 500 サイクルでも約 7\% RH の増加と 
小さ々，耐水性に優れている。

ポリイミド感湿膜の最適化や上部 $\mathrm{Au}$ 電極の保護膜 形成を行っていない従来のポリイミド容量型湿度セン サ(5)では, 結露していない $85^{\circ} \mathrm{C} ・ 85 \% \mathrm{RH}$ の環境下で の試験においてさえも，初期において約 $12 \% \mathrm{RH}$ 相 当の変動を示し, 約 2,000 時間後から急速な劣化が更 に進み $20 \% \mathrm{RH}$ 以上の変化となる。また， $85^{\circ} \mathrm{C} ・ 100$ $\% \mathrm{RH}$ の環境下では最初から劣化が進み, 約 1,000 時 間で $20 \% \mathrm{RH}$ も初期值から变化してしまっている。

今回の実験では全く同一の試験は行っていないが, 図 13 に示したように結露をさせるという過酷な環境 を加えているにもかかわらず，約 7\% RH の経時変化 であり, 感湿膜の最適化や電極保護膜の形成によって 信頼性が向上したことは明らかである。また，特殊な 環境の例として, $\mathrm{H}_{2} \mathrm{~S}$ ガス・ $100 \mathrm{ppm} ・ 24$ 時間や, ア セトン・ $1 \% \cdot 24$ 時間の放置後の特性変化などについて も評価したが，3\% RH 以内の変化にとどまってお $\eta^{(8)}$, 信頼性が高いことを示している。

\section{6. むす び}

本研究では, 裹面に電極をつけた $\mathrm{Si}$ 基板上に約 $1.2 \mu \mathrm{m}$ のポリイミド層を直接形成し，その上に櫛型 $\mathrm{Au}$ 電極をもつ構造の容量型湿度センサにおいて，そ の信頼性向上を図るため, 異なる性質をもつポリイミ ド樹脂を配合して用いることを検討した。その結果, 各々のポリマがもつ欠点を補いながら, 互いの長所を 合わせもつ特性の湿度センサが製作できることを見い だした。

この技術を用いて容量型湿度センサを作成し, 感湿 特性をはじめ種々の負荷に対する安定性の評価を行っ た結果, 高精度な湿度計測が広い湿度範囲で可能で, かつ信頼性も高い湿度センサを実現できた。

(平成 4 年 5 月 22 日受付, 同 5 年 1 月 22 日再受付)

\section{文献}

（1）佐藤：「高分子湿度七ンサ」, 七ンサ技術, 9, No.7, 80 (平元)

（2）坂東・前橋：「熱硬化型湿度センサとその特性」, 同上, 3 , No. 7, 80 (昭 58)

(3) H. Grange, C. Bieth, H. Boucher \& G. Delapierre: "A capacitive humidity sensor with very fast response time and very low hysteresis", Sensor \& Actuators, 12, 291 (1987)

（4）桜井：「ヒューミキャップ湿度センサ」，センサ技術，2， No. 6, 175 (昭 57)

(5) M. C. Glenn \& S. A. Schuetz: "An IC compatible polymer humidity sensor", Digest of Technical Papers of Trans. ducer '85, p. 217 (1985)

(6) P. J. Schubert \& J.H. Nevin: “A polyimide-based capacitive humidity sensor", IEEE Trans. Electron Devices, ED-32, No. 7, 1220 (1985)
（7）村上・山本・清水・高井：「Si 基板上にポリイミドを塾布し た容量型湿度センサ」, 第 47 回応用物理学会秋季予稿集, 29 a-ZB-8（昭 61）

(8) T. Takai, T.Sakamoto, H. Shimizu, K. Murakami \& T. Yamamoto: "A capacitive polymer humidity sensor using silicon substrate", Technical Digest of the 7th Sensor Symposium, p. 185 (1988)

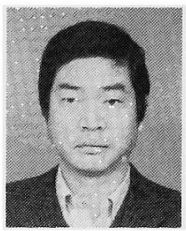

\section{坂 本 哲 野 (非会員)}

昭和 24 年 9 月 22 日生。 47 年静岡大 学工学部工業化学科卒業。52 年(株)ク ラべ入社。高分子応用製品の開発扝よび センサデバイスの開発に従事。

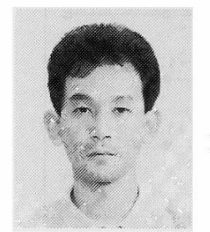

\section{兼 堀 正 史 (非会員)}

昭和 39 年 11 月 17 日生。62 年工学院 大学工学部電子工学科卒業。同年(株) ク ラベ入社。センサデバイスの開発に従事。

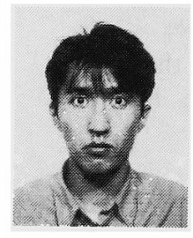

\section{竹上 喜 紳 (非会員)}

昭和 40 年 10 月 19 日生。63 年愛知工 業大学工学部電気工学科卒業。同年(株) クラベ入社。センサデバイスの開発に従 事。

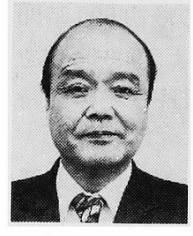

山本 達 夫（正員）

大正 14 年 12 月 1 日生。昭和 25 年東 北大学工学部電気工学科卒業。38 年静 岡大学工学部付属電子工学研究施設助教 授, 49 年同大学電子工学研究所教授。 平成元年石巻専修大学理工学部電子材料工学科教授。主と して, 化学センサの研究に従事。

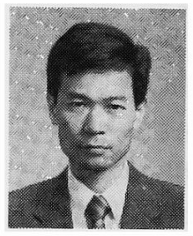
中 込 真 二 (非会員)

昭和 31 年 2 月 12 日生。 53 年山梨大 学工学部電子工学科卒業。59 年東北大 学大学院博士課程修了。同年 (財) 半導体 研究振興会半導体研究所研究員。平成元 年石巻専修大学理工学部電子材料工学科助教授。工学博 士。機能素子の研究に従事。 